\title{
1 Kinetics of amino sugar formation from organic residues 2 of different quality
}

3

4 Zhen Bai ${ }^{\mathrm{a}, \mathrm{b}, 1}$, Samuel Bodé ${ }^{\mathrm{a}, 1}$, Dries Huygens ${ }^{\mathrm{a}, \mathrm{c}}$, Xudong Zhang $^{\mathrm{b}}$, Pascal Boeckx ${ }^{\mathrm{a} *}$ 5

$6 \quad{ }^{\mathrm{a}}$ Isotope Bioscience Laboratory - ISOFYS, Ghent University, Ghent, Belgium

$7 \quad{ }^{b}$ State Key Laboratory of Forest and Soil Ecology, Institute of Applied Ecology, Chinese Academy of

8 Sciences, Shenyang, P. R. China

9 Institute of Agricultural Engineering and Soil Science, Faculty of Agricultural Sciences, Universidad

10 Austral de Chile, Valdivia, Chile

$11{ }^{1}$ Equal contribution of both authors

14 Amino sugars are key compounds of microbial cell walls, which have been widely 15 used as biomarker of microbial residues to investigate soil microbial communities and 16 organic residue cycling processes. However, the formation dynamics of amino sugar 17 is not well understood. In this study, two agricultural Luvisols under distinct tillage 18 managements were amended with uniformly ${ }^{13} \mathrm{C}$-labeled wheat residues of different 19 quality (grain, leaf and root). The isotopic composition of individual amino sugars and $20 \mathrm{CO}_{2}$ emission were measured over a 21-day incubation period using liquid 21 chromatography - isotope ratio mass spectrometry (LC-IRMS) and trace gas IRMS. 22 Results showed that, the amount of residue derived amino sugars increased 23 exponentially and reached a maximum within days after residue addition.

24 Glucosamine and galactosamine followed different formation kinetics. The maxima of 25 residue derived amino sugars formation ranged from $14 \mathrm{nmol} \mathrm{g}^{-1}$ dry soil for 26 galactosamine $\left(0.8 \%\right.$ of the original concentration) to $319 \mathrm{nmol} \mathrm{g}^{-1}$ dry soil for 27 glucosamine (11\% of the original concentration). Mean production times of residue

\footnotetext{
* Corresponding author: Tel. +32926460 00, pascal.boeckx@ugent.be
} 
derived amino sugars ranged from 2.1 to 9.3 days for glucosamine and galactosamine, respectively. In general, larger amounts of amino sugars were formed at a higher rate with increasing plant residue quality. The microbial community of the no-till soil was better adapted to assimilate low quality plant residues (i.e. leaf and root). All together, the formation dynamics of microbial cell wall components was component-specific and determined by residue quality and soil microbial community.

\section{Key words}

Amino sugar, Kinetics, Organic residue, Tillage, Carbon-13, LC-IRMS

\section{Introduction}

One of the most significant impacts that microbial communities have on their environment is their ability to recycle essential elements that make up their cells. Soil organic carbon (SOC) is mainly degraded by microbes and then assimilated into living matter or respired to generate energy for cellular processes (Glaser et al. 2004, Perelo and Munch 2005). Therefore, there is a considerable interest in understanding the biological mechanisms that regulate $\mathrm{C}$ exchanges between the land and atmosphere, including microbial metabolism (Allison et al. 2010). Amino sugars are useful microbial biomarkers to investigate the dynamics of microbial communities due to their prevalence in the cell walls of microorganisms, their insignificant content in plant residues and their recalcitrance after cell death (White 1968; Amelung et al. 2001; Glaser and Gross 2005; He et al. 2005; Liang and Balser 2010). While 26 amino sugars have been identified in microorganisms, only four of them have been quantified in soil, i.e. glucosamine, galactosamine, mannosamine and muramic acid (Amelung et al. 2008). Glucosamine is most abundant (50-65 \%), followed by galactosamine (30-44\%) and muramic acid (4-6\%), while mannosamine is typically low in soils (Engelking et al. 2007; Ding et al. 2010). Over 90\% of amino sugars are found in dead cells (Amelung et al. 2001). Therefore, the amino sugar content is used to quantify microbial residues rather than a proxy for living microbial biomass and activity (van Groenigen et al. 2010). Glucosamine in soil is mainly derived from chitins of fungal cell walls, though it also occurs in bacteria. Muramic acid exclusively originates from peptidoglycans of bacterial cell walls (Farkas 1979; 
Amelung et al. 2001, 2008; He et al. 2005). While muramic acid can be directly attributed to bacterial residue, the glucosamine content has to be corrected for the bacterial glucosamine contribution in order to use it as an estimate of fungal residues (Amelung et al. 2008; He et al. 2011a). The origin of galactosamine is less clear and is typically considered to be nonspecific, as actinomycetes, bacteria and fungi all likely contain considerable galactosamine amounts (He et al. 2005; Ding et al. 2010). Amino sugars have been used to investigate soil microbial residues. However, little is known about the kinetics of amino sugar formation. Albeit the mean age of amino sugar carbon might be similar to or even older than bulk SOM (Derrien et al. 2006), we anticipate that the new, residue derived, amino sugar formation rate might be fast, considering the high turnover rates of microbial cell walls (Mauck et al. 1971; Park 2001).

Crop residues provide resources for soil microbial metabolism thereby stimulating amino sugar buildup in soil (Mauck et al. 1971; Park 2001), and vary in their relative amounts of easily decomposable and more recalcitrant compounds. The easily decomposable compounds are exhausted in a very short time period and induce a quick build-up of microbial biomass. Rousk and Bååth (2007) showed that soil $\mathrm{CO}_{2}$ flux peaked between day two and four while fungal and bacterial growth rates reached maxima between day three and seven after residue incorporation. Sauheitl et al. (2005) demonstrated an exponential incorporation of plant-derived carbon into microbial sugars reaching a maximum within 4 days after substrate addition. Marx et al. (2010) showed that almost half of total soil microbial biomass $\mathrm{C}$ was replaced by substrate-derived $\mathrm{C}$ two days after the incubation of ${ }^{13} \mathrm{C}$-labeled organic compounds, which suggests a very rapid turnover of the microbial biomass.

Therefore, the aim of this study is to elucidate residue derived amino sugar formation kinetics during the peak $\mathrm{CO}_{2}$ respiration following plant residue incorporation. We tested the following hypotheses: (1) Since bacteria are thought to play an important role in early stage degradation of new carbon sources, i.e. 'fast energy channel' sensu Rousk and Bååth (2007) we expect a faster incorporation of residue carbon into bacterial amino sugar than fungal amino sugar; (2) Given that fungi are thought to be 

111 seeding).

better adapted to degrade more recalcitrant carbon sources compared to bacteria (Myers et. al 2001; Waldrop and Firestone 2004) we expect a larger effect of residue quality on the formation of bacterial amino sugars compared to fungal amino sugars; and (3) for the same reasons we expect that a higher fungal/bacteria ratio will result in higher amino sugars formation from low quality residues.

To test these hypotheses we carried out a laboratory incubation experiment in which uniformly ${ }^{13} \mathrm{C}$-labeled crop residues of different quality (wheat grain, leaves and roots) were incubated in two soils with a distinct tillage management affecting the fungi-to-bacteria ratio. The amino sugar formation dynamics were determined by measuring the evolution of the ${ }^{13} \mathrm{C}$ content of individual amino sugars via liquid chromatography - isotope ratio mass spectrometry (LC-IRMS).

\section{Materials and methods}

\subsection{Soil description, sampling and incubation}

\section{Site description}

The study site was located in Maulde, Belgium $\left(50^{\circ} 37^{\prime} \mathrm{N}, 3^{\circ} 34^{\prime} \mathrm{E}\right)$. The climate is characterized as temperate and humid marine with a 30-year mean precipitation of $780 \mathrm{~mm}$ per year and a mean maximum and minimum temperature of 13.5 and $6.3^{\circ} \mathrm{C}$, respectively. The soil is classified as a Luvisol (FAO 2006). The field site has been under arable land over 100 years and was converted from conventional tillage (moldboard plowing until $30 \mathrm{~cm}$ and harrowing of the top $10 \mathrm{~cm}$ ) to reduced tillage (harrowing of the top $10 \mathrm{~cm}$ ) in 1995. In 2006, one third of the field was re-converted to conventional tillage, another third to "no-till" (no soil disturbance and direct

\section{Soil sampling strategy and pre-incubation}

113 On November 9, 2010, topsoils $(0-10 \mathrm{~cm})$ of the conventional tilled soil (CT) and 114 "no-till" soil (NT) of the study field were collected from randomly selected locations 
115 at each site. The fresh soil was handpicked to remove plant or animal residues, sieved

$116(<2 \mathrm{~mm})$ and stored at $4{ }^{\circ} \mathrm{C}$ for one day before the start of the pre-incubation. The

117 fresh soil was adjusted to $20 \%(\mathrm{~m} / \mathrm{m})$ moisture content and pre-incubated at $24{ }^{\circ} \mathrm{C}$

118 under aerobic conditions for 5 days. Basic properties of collected soils are described 119 in Table 1.

\section{Incubation with uniformly ${ }^{13}$ C-labeled wheat residues}

121 The ${ }^{13} \mathrm{C}$-labeled roots, leaves and grains originated from uniformly ${ }^{13} \mathrm{C}$-labeled wheat

122 (Triticum aestivum), which had been grown with ${ }^{13} \mathrm{CO}_{2}$ (2 atom\% excess) (Denef and

123 Six 2006). The plant material was collected and dried at $45{ }^{\circ} \mathrm{C}$ and stored at room

124 temperature until incubation. Plant quality was assessed on the basis of $\mathrm{C}: \mathrm{N}$, lignin: $\mathrm{N}$,

125 hemicellulose, cellulose and polyphenol content (Table 2). Residues were ground to a

126 size $<250 \mu \mathrm{m}$ and thoroughly mixed with the soil to facilitate substrate decomposition.

127 An application rate of $6 \mathrm{mg}$ substrate- $\mathrm{C} \mathrm{g}^{-1}$ dry soil was used in six treatments: NG

128 (NT with grain residue), NL (NT with leaf residue), NR (NT with root residue), CG

129 (CT with grain residue), CL (CT with leaf residue), and CR (CT with root residue).

130 There were three microcosm replicates for each treatment.

131 The soil (15 g) with ${ }^{13} \mathrm{C}$-residues was placed in plastic container covered by aluminum

132 foil with small holes to allow $\mathrm{O}_{2}$ and $\mathrm{CO}_{2}$ exchange. The incubation temperature was

133 maintained at $24{ }^{\circ} \mathrm{C}$ and the moisture content was kept at $20 \%$ (w/w) by adding

134 MilliQ water every 2-3 days. After 0, 9, 24, and 45 hours, and 3, 5, 10 and 21 days,

135 mineralization rate was measured and samples were collected destructively by

136 freezing microcosms instantaneously in liquid nitrogen followed by lyophilization.

137 The subsamples were stored at $-20{ }^{\circ} \mathrm{C}$ for subsequent analyses.

\section{2.2. Carbon mineralization rate}

$139 \mathrm{CO}_{2}$ respiration rates were measured by placing the microcosms in an airtight glass jar 140 with rubber septa to allow gas sampling. The jars were kept closed for 5 hours and gas 141 samples were withdrawn after $0 \mathrm{~h}, 0.5 \mathrm{~h}, 3 \mathrm{~h}$ and $5 \mathrm{~h}$. The $\mathrm{CO}_{2}$ concentration was 142 determined with a gas chromatograph (Shimadzu 14B, Japan) equipped with a $2 \mathrm{~m}$ 
143 Porapak Q column (2.2 mm o.d., SS 80/100), a pre-column (1 m) of the same material, 144 both at $55^{\circ} \mathrm{C}$, and a ${ }^{63} \mathrm{Ni}$ electron capture detector (ECD) at $250{ }^{\circ} \mathrm{C}$. To determine the 145 portion of the respired $\mathrm{CO}_{2}$ originating from the mineralization of added plant 146 residues, the isotopic composition of respired $\mathrm{CO}_{2}$ was determined using a trace gas 147 preparation unit (ANCA-TGII, SerCon, UK) coupled to an isotope ratio mass 148 spectrometer (IRMS) (20-20, SerCon, UK).

149 Respiration rate $(v)$ was determined using the slope of a linear regression of the $\mathrm{CO}_{2}$ 150 concentrations as a function of time and the isotopic composition of the respired $\mathrm{CO}_{2}$ 151 was calculated as:

$\delta^{13} \mathrm{C}_{\text {resp }}=\frac{\mathrm{n}_{1} \cdot \delta^{13} \mathrm{C}_{1}-\mathrm{n}_{2} \cdot \delta^{13} \mathrm{C}_{2}}{\mathrm{n}_{1}-\mathrm{n}_{2}}$

153 With $\mathrm{n}_{1}, \mathrm{n}_{2}, \delta^{13} \mathrm{C}_{1}$ and $\delta^{13} \mathrm{C}_{2}$ are the amount and isotopic composition of the $\mathrm{CO}_{2}$ in the 154 airtight glass jar measured at two different sampling points.

155 The fraction of $\mathrm{CO}_{2}$ derived from the added residue $\left(f \mathrm{M}_{\mathrm{R}, \mathrm{t}}\right)$ was calculated as:

156

$$
f \mathrm{M}_{\mathrm{R}, \mathrm{t}}=\left(\frac{\delta^{13} \mathrm{C}_{\text {resp }, \mathrm{t}}-\delta^{13} \mathrm{C}_{\text {resp }, 0}}{\delta^{13} \mathrm{C}_{\mathrm{R}}-\delta^{13} \mathrm{C}_{\mathrm{SOM}}}\right) \times 100
$$

157 With $\delta^{13} \mathrm{C}_{\text {resp,t }}$ and $\delta^{13} \mathrm{C}_{\text {resp, }, 0}$, being the $\delta^{13} \mathrm{C}$ values of the respired $\mathrm{CO}_{2}$ at time point $\mathrm{t}$ 158 and by a control soil, the respectively and $\delta^{13} \mathrm{C}_{\mathrm{R}}$ and $\delta^{13} \mathrm{C}_{\mathrm{SOM}}$ are respectively the $\delta^{13} \mathrm{C}$ 159 of the added residues and SOM. The $\mathrm{CO}_{2}$ respiration rate attributed to the added plant 160 residue $\left(v_{\mathrm{R}}\right)$ was calculated as:

$161 \quad v_{\mathrm{R}}=v \cdot f \mathrm{M}_{\mathrm{R}, \mathrm{t}}$

162 with $v$ the total measured $\mathrm{CO}_{2}$ respiration. To estimate the amount of residue carbon 163 readily available for mineralization $\left(\mathrm{C}_{\mathrm{M}}\right)$ the area under the residue-derived $\mathrm{CO}_{2}$ 164 mineralization peak (Fig 1) was determined, assuming a constant change in $\mathrm{CO}_{2}$ 165 production rate between two adjacent sampling points.

\subsection{Amino sugar analysis}

168 The amino sugar extraction procedure was based on the method described by Bodé et 169 al. (2009). Briefly, c.a. $0.2 \mathrm{~g}$ soil was hydrolyzed for 8 hours at $105{ }^{\circ} \mathrm{C}$ using $10 \mathrm{~mL}$ $1706 \mathrm{M} \mathrm{HCl}$. Thereafter, the soil suspension was filtered (GF/C 25mm, Whatman) using a 
reusable syringe filter device (Millipore, SWINNEX). Water and $\mathrm{HCl}$ were removed by evaporating under reduced pressure at $45^{\circ} \mathrm{C}$, and the concentrated amino sugar sample was re-dissolved in MilliQ water. After purification by a cation exchange resin, the amino sugar solution was dried and re-dissolved with $1.5 \mathrm{~mL}$ MilliQ water. Concentration and $\delta^{13} \mathrm{C}$ of amino sugar were determined by liquid chromatography-isotope ratio mass spectrometry (LC-IRMS) (Thermo Electron, Bremen, Germany). We refer to Bodé et al. (2009) for more details on the amino sugar extraction procedure.

The fraction of amino sugar originated from the ${ }^{13} \mathrm{C}$-labeled residues at a time point $\mathrm{t}$ was calculated as:

$$
f \mathrm{AS}_{\mathrm{R}, \mathrm{t}}=\left(\frac{\delta^{13} \mathrm{C}_{\mathrm{AS}, \mathrm{t}}-\delta^{13} \mathrm{C}_{\mathrm{AS}, \mathrm{t}_{0}}}{\delta^{13} \mathrm{C}_{\mathrm{R}}-\delta^{13} \mathrm{C}_{\mathrm{SOM}}}\right)
$$

whereby $\delta^{13} \mathrm{C}_{\mathrm{R}}$ and $\delta^{13} \mathrm{C}_{\mathrm{SOM}}$ are the ${ }^{13} \mathrm{C}$ isotopic composition of the added residues and original SOM respectively. The $\delta^{13} \mathrm{C}_{\mathrm{AS}, \mathrm{t}}$ and $\delta^{13} \mathrm{C}_{\mathrm{AS}, \mathrm{t} 0}$ are respectively the isotopic composition of the amino sugar of interest at time $t$ and at the start of the incubation experiment. It has to be noted that the $\delta^{13} \mathrm{C}_{\mathrm{AS}, \mathrm{t} 0}$ was not identical to the original isotopic composition of the soil amino sugar $\left(\mathrm{AS}_{0}\right)$ due the presence of ${ }^{13} \mathrm{C}$ labeled amino sugars in the plant residues. Since plants do not produce amino sugars (Amelung et al. 2008), this is likely explained via the presence of endophytic bacteria and fungi (Appuhn et al. 2004, Reinhold-Hurek and Hurek 2011) in the labeled plant material (Table 2).

An important fluctuation on the measured concentration of the unlabeled amino sugar pool between sampling time points was observed (see SI1), however these fluctuations did not show any trend (except a very slight increase for glucosamine in NG). Since the amino sugar pool is known to be rather stable (Glaser and Gross 2005) and although priming (positive and negative) cannot be excluded (Bell et al. 2003, Blagodatskaya et al. 2007) we expect these fluctuation to be mainly due to variability in extraction efficiency or bias in analytical response, the later was also supported by a very similar deviations for galactosamine and glucosamine. Therefore in order to have the best possible estimation of the amount residue derived amino sugar produced, 
the newly formed amino sugar concentration was standardized to the unlabeled amino

200 sugar pool (see SI2).

\subsection{Bulk soil isotopic analysis}

203 Subsamples of air-dried soil samples were ground by a planetary ball mill (PM400, 204 Retsch, Germany) for total $\mathrm{C}$ and $\mathrm{N}$, and ${ }^{13} \mathrm{C}$ and ${ }^{15} \mathrm{~N}$ analysis by an elemental analyzer (EA) (ANCA-SL, SerCon, UK) coupled to an IRMS (20-20, SerCon, UK).

\subsection{Statistical analysis}

208 Statistical analysis was performed using SPSS 19.0. A three-way analysis of variance (ANOVA) procedure with Tukey's HSD (Honestly Significant Difference) post hoc test was used to analyze the effects of plant residue quality, amino sugar identity and

211 tillage on amino sugar formation and C mineralization using a general linear model.

212 When a significant interactions between factors was observed this interaction was 213 investigated by repeating the statistical test for the different levels of the interacting 214 factors individually. Unless otherwise stated significant level of difference was set at $\alpha$ $215=0.05$. Non-linear regression analysis was used to determine $k$ and maxima in 216 non-linear equation (5).

\section{3. Results}

\section{$218 \quad 3.1 . \quad$ Carbon mineralization}

219 Residue mineralization started immediately after residue addition and $\mathrm{CO}_{2}$ flux 220 peaked between day 1 and 3 across treatments (Fig. 1) after which it decreased again 221 to reach constant "steady state mineralization rate" at day 10. The amount of carbon 222 readily available for mineralization $\left(\mathrm{C}_{\mathrm{M}}\right)$ ranged from 23 till $84 \mu \mathrm{mol} \mathrm{g} \mathrm{g}^{-1}$ dry soil with 223 highest $\mathrm{C}_{\mathrm{M}}$ for grain incubated soils and lowest for root incubated ones. At the end of 224 the experiment the amount of residue mineralized (total cumulative amount 225 mineralized during the 21 days incubation) was between $10 \%$ (root) and $26 \%$ (grain) 226 of the added plant residue (Fig. 1).

\section{3.2. Original amino sugar concentration}

228 The original concentration of amino sugar was higher for no-till site compared to 
conventional tilled one $(\mathrm{F}=14, \mathrm{P}<0.001)$ (Table 4). The highest amounts were found

230 for glucosamine ( $3781 \pm 66 \mathrm{nmol} \mathrm{g}^{-1}$ dry soil for the no-till treatment and $2985 \pm 199$

$231 \mathrm{nmol} \mathrm{g}{ }^{-1}$ dry soil for the conventional till treatment) followed by galactosamine (1937

$232 \pm 102$ (no-till) and $1742 \pm 110 \mathrm{nmol} \mathrm{g}^{-1}$ dry soil (conventional till))(Table 3) and

233 lowest for muramic acid $\left(657 \pm 240\right.$ (no-till) and $522 \pm 171 \mathrm{nmol} \mathrm{g}^{-1}$ dry soil

234 (conventional till) $(\mathrm{F}=240, \mathrm{P}<0.001)$ (Table 4). Additionally, there was a small but

235 significant effect of the tillage treatment on amino sugar type $(\mathrm{F}=4.13, \mathrm{P}<0.05)$, with

236 larger differences in concentration for the different amino sugars in the no-till soil (F

$237=217)$ compared to conventional tilled soil $(\mathrm{F}=73)$ (Table 4).

238 3.3. Model approach for parameter estimation of residue-derived amino sugar 239 formation kinetics

240 Similarly to the residue mineralization, the incorporation of ${ }^{13} \mathrm{C}$ - carbon derived from

241 the added residues into the amino sugar pool was detected from the first sampling 242 point (9 hours) on and it increased exponentially during the first days of the 243 incubation after which residue derived amino sugars formation reached a steady state 244 (Fig. 2).

245 A first-order kinetic model was fitted to the formation dynamics of residue-derived 246 glucosamine and galactosamine (Fig. 2):

$247 \quad \mathrm{AS}_{\mathrm{R}}=\mathrm{AS}_{\mathrm{R}, \mathrm{Max}} \cdot\left(1-\mathrm{e}^{-k \cdot \mathrm{t}}\right)$

248 with $\mathrm{AS}_{\mathrm{R}, \text { Max }}$ being the maximum of the exponential residue derived amino sugar 249 formation, $\mathrm{AS}_{\mathrm{R}(\mathrm{t})}$ is the amount residue derived amino sugar at time $\mathrm{t}$ and $k$ the 250 formation rate constant of the exponential formation of residue derived amino sugars. 251 The inverse of $k$ is the mean production time (MPT), which is the average time 252 needed to form "de novo" residue derived amino sugars during the microbial peak 253 activity (see Appendix):

$254 \quad \mathrm{MPT}=\frac{1}{k}$

255 The $\mathrm{AS}_{\mathrm{R}, \text { Max }}$ of glucosamine and galactosamine ranged from 40 till $319 \mathrm{nmol} \mathrm{g}^{-1}$ and 25614 till $98 \mathrm{nmol} \mathrm{g}^{-1}$ respectively. MPT of glucosamine and galactosamine ranged from $257 \quad 1.6$ to 3.7 days and from 2.1 to 8.3 days respectively (Table 3 ). 
258 Unfortunately the high ${ }^{13} \mathrm{C}$ enrichment of muramic acid at start of the incubation (due 259 to considerable amount of muramic acid present in the labeled plant residue (Table 2) 260 relative to the low soil muramic acid concentration) and higher variability on 261 concentration and isotopic measurements of muramic acid, impeded the determination 262 of the dynamics of residue derived formation of muramic acid in this incubation 263 experiment (Fig. 2).

\subsection{Effect of residue quality, amino sugar type and tillage treatment}

266 The effect of amino sugar type, residue quality and tillage history of the soil on 267 parameters describing the dynamics of residue derived amino sugar formation $268\left(\mathrm{AS}_{\mathrm{R}, \mathrm{Max}}, k\right.$ (equation 4$)$ and on $\mathrm{AS}_{\mathrm{R}, \mathrm{Max}}$ relative to the original amino sugar 269 concentration) was investigated using a multi-way ANOVA approach (Table 4).

\section{Maxima of residue derived amino sugar formation $\left(A S_{R, M a x}\right)$}

271 There was a significant effect of amino sugar type, residue quality and tillage history 272 on $\mathrm{AS}_{\mathrm{R}, \mathrm{Max}}$. The formation of the different amino sugars followed dissimilar kinetics, 273 with greatest $\mathrm{AS}_{\mathrm{R}, \mathrm{Max}}$ values obtained for glucosamine (40 to $319 \mathrm{nmol} \mathrm{g}{ }^{-1}$ dry soil) 274 than for galactosamine (14 to $98 \mathrm{nmol} \mathrm{g}^{-1}$ dry soil) (Table 3 and 4). The comparison of $275 \mathrm{AS}_{\mathrm{R}, \text { Max }}$ values among residue quality indicated that the values were greater for grain 276 (198 $\mathrm{nmol} \mathrm{g}^{-1}$ dry soil, averaged over all amino sugar type-tillage combinations) 277 followed by leaf (137 $\mathrm{nmol} \mathrm{g}^{-1}$ dry soil) and root (45 $\mathrm{nmol} \mathrm{g}^{-1}$ dry soil) (Table 3 and 4).

278 The no-till soil (134 $\mathrm{nmol} \mathrm{g}^{-1}$ dry soil, averaged over all amino sugar type-residue 279 combinations) generally showed greater $\mathrm{AS}_{\mathrm{R}, \mathrm{Max}}$ values than conventional tilled one 280 (119 $\mathrm{nmol} \mathrm{g}^{-1}$ dry soil). Additionally, significant interactive effects between amino 281 sugar type and residue quality $(\mathrm{F}=130)$, residue quality and tillage history of the soil 282 sample $(\mathrm{F}=19.1)$ (Table 4) were observed. The interaction between amino sugar type 283 and residue quality indicated that the differences in $\mathrm{AS}_{\mathrm{R}, \mathrm{Max}}$ between glucosamine and 284 galactosamine were more prominent for grain incubations $(F=722)$ than for leaf $(F=$ $285337)$ and root $(\mathrm{F}=45.6)$, while quality of residue had a greater effect on glucosamine 
$286(\mathrm{~F}=287)$ than on galactosamine $(\mathrm{F}=221)$ (Table 3 and 4$)$. The interaction of residue

287 quality and tillage treatment of the soil sample revealed a greater effect of residue 288 quality in the conventional tilled soil $(\mathrm{F}=391)$ compared to no-till soil $(\mathrm{F}=121)$. 289 Tillage history of the soil sample had a larger effect for root $(F=28.5)$ than for leaf $(F$ $290=19.3$ ) while the effect of tillage history was inverted for grain incubated samples $291 \mathrm{AS}_{\mathrm{R}, \mathrm{Max}}$ was highest for the conventional tilled soil $(\mathrm{F}=7.4)$ (Table 4).

\section{Formation rate constant $(k)$ and mean production time (MPT)}

293 A significant effect of residue quality and amino sugar type on the formation rate was 294 observed. There was no effect of the tillage history. Glucosamine was formed at a 295 greater rate compared to galactosamine (Table 4) with an average MPT of 3.2 and 4.9 296 days (Table 3), respectively. Comparing the formation rates among residue quality, 297 indicated that the values were greatest for grain $\left(0.40 \mathrm{day}^{-1}\right.$, averaged over all amino 298 sugar type-tillage combinations), followed by root $\left(0.27\right.$ day $\left.^{-1}\right)$ and leaf $\left(0.19\right.$ day $\left.^{-1}\right)$, 299 which did not differ significantly (Table 4). No interactive effects were observed.

\section{$A S_{R, M a x}$ relative to the original amino sugar concentration}

301 The effects of the tested factors on the ratio $\mathrm{AS}_{\mathrm{R}, \mathrm{Max}}$ to original amino sugar were, in 302 general, similar to the effects observed on $\mathrm{AS}_{\mathrm{R}, \mathrm{Max}}$ (Table 4). Exceptions were the 303 absence of the effect of tillage history and an additional interaction between amino 304 sugar type and tillage history $(\mathrm{F}=32.3)$ with a larger tillage effect on glucosamine $(\mathrm{F}$ $305=5.52)$ formation than on galactosamine $(\mathrm{F}=0.562)$ (Table 4$)$.

\section{Discussion}

308 In contrast to most previous works, this study was able to successfully quantify newly

309 formed amino sugars during peak microbial activity following plant residue addition.

310 De novo formed amino sugars could be approximated by the residue derived amino 311 sugars as the unlabeled amino sugar pool did not vary significantly of over time (SF1). 312 Noticeably, soil microorganisms prefer to feed on fresh organic residues rather than 
313 on endogenous SOM during exponential microbial activity following residue addition 314 (Amelung et al. 2008).

315 The MPT of the amino sugar, defined here as the average time needed to form " $d e$ 316 novo" residue derived amino sugar during peak microbial activity following plant 317 residue addition, varied between 2.1 and 9.3 days. Maxima of the exponential 318 microbial amino sugars formation were attained within ca. one week after which the 319 residue derived amino sugars formation reached a steady state (Table 3, Fig. 2). 320 Decock et al. (2009) also revealed a maximum $\delta^{13} \mathrm{C}$ in glucosamine and 321 galactosamine within one week after incubation using ${ }^{13} \mathrm{C}$-labeled wheat residues. 322 Liang et al. (2007) reported that amino sugar content in black soil reached a maximum 323 within 3 weeks upon incubation with maize residue, thereby increasing the original 324 amino sugar content with one third.

\section{$325 \quad$ 4.1. Effect of amino sugar type}

326 As muramic acid exclusively originates from bacterial cell wall, while glucosamine 327 and galactosamine are present in both bacterial as fungal residues (Amelung et al. 3282001 and 2008; Glaser and Gross 2005; Engelking et al. 2007), muramic acid is the 329 preferred biomarker to differentiate bacterial and fungal activity for incorporation of 330 residue-derived carbon. Unfortunately, due to a higher uncertainty on the muramic 331 acid measurements and a high ${ }^{13} \mathrm{C}$-muramic acid contamination of the plant residues 332 the formation dynamics of muramic acid could not be determined.

333 The $\mathrm{AS}_{\mathrm{R}, \mathrm{Max}}$ relative to the original soil amino sugar concentration ranged from 1.3 to $33411 \%$ for glucosamine followed by galactosamine (0.8 to 5.7\%). A similar trend was 335 also observed in other studies (Glaser and Gross 2005; Engelking et al. 2007; He et al. 336 2011b).

337 Bacteria and fungi both produce glucosamine and galactosamine (Amelung et al. 2001 338 and 2008; Glaser and Gross 2005). However, the strong amino sugar-type effect on $339 \mathrm{AS}_{\mathrm{R}, \mathrm{Max}}$ relative to the original amino sugar concentration, and on the MPT, indicate 340 that these amino sugars are formed through dissimilar processes. Engelking et al. 341 (2007) reviewed the available literature on amino sugar concentrations in cultured 342 bacteria and fungi, which revealed that the galactosamine/glucosamine ratio appeared 
343 to be on average almost 3 times higher in fungi compared to bacteria, making residue

344 derived galactosamine a 'more' fungal marker than glucosamine when considering 345 microbial activity. The higher formation rate constant of glucosamine compared to 346 galactosamine thus most likely indicates that bacteria play a more important role for 347 early stage incorporation of residue-derived carbon, i.e. 'fast energy channel' sensu 348 Rousk et al., 2007). The slower formation of galactosamine, corroborates with the 349 slower turnover of fungi compared to bacteria; for which fungi are involved in the 350 slow energy channel through the soil food web (Rousk et al. 2007).

\section{$351 \quad$ 4.2. Effect of Residue quality}

352 Exponential residue derived amino sugar formation during the first days after residue 353 addition was accompanied with high carbon mineralization rates (Fig. 1 and 2). 354 Carbon mineralization and microbial growth upon residue decomposition is largely 355 determined by organic matter quality (Liang et al. 2007; Rousk and Bååth 2007). The 356 high $\mathrm{C}: \mathrm{N}$ and lignin content of root indicates its low quality while grain had the 357 highest quality. This difference in quality was also revealed by the amount of readily 358 available carbon. Altogether this resulted in different $\mathrm{AS}_{\mathrm{R}, \mathrm{Max}}$ values between residues: 359 grain $>$ leaf $>$ root $(\mathrm{P}<0.001)$.

360 The interaction between residue quality and amino sugar type revealed that the 361 difference between the $\mathrm{AS}_{\mathrm{R}, \mathrm{Max}}$ for glucosamine and galactosamine was much more 362 pronounced for grain compared to leaf and root (both absolute as relative to the 363 original amino sugar concentration). Considering the higher fungal origin of 364 galactosamine, this interaction indicates that, at least during peak microbial activity, 365 fungi seem to be less dependent on the quality of the residue than bacteria for de novo 366 amino sugar formation. This is in accordance with what we expected since it is 367 generally believed that bacteria especially rely on easily available $\mathrm{C}$ compounds while 368 the fungal community is better adapted to colonize more recalcitrant sources (Myers 369 et al. 2001; Waldrop and Firestone 2004).

$370 \quad$ 4.3. Effect of the site's tillage history

371 The increased ability of the no-till soil samples to enhance mineralization and amino 372 sugars formation out of residues of lower quality may be explained by microbial 
community differences typically found in not tilled soil. Fungi, showing a great ability to decompose more recalcitrant substrates (Acosta-Martinez et al. 2003; Ding et al. 2010; Werth and Kuzyakov 2010), are typically more abundant in the no till soils (Fu et al. 2000; Thiet et al. 2006; White and Rice 2009).

Furthermore comparing the amount amino sugars formed during peak microbial activity $\left(\mathrm{AS}_{\mathrm{R}, \text { Max }}\right.$ of glucosamine $+\mathrm{AS}_{\mathrm{R}, \mathrm{Max}}$ of galactosamine) relative to the readily available carbon of the residue (estimated by $\mathrm{C}_{\mathrm{M}}$ ), the no-till soil showed an enhanced ability to form more amino sugars from the readily available carbon of the lower quality residues (leaf and root) while this was not different for grain.

The difference in microbial community in both soils was, however, not significantly reflected in the ratio of the masses of fungal and bacterial residues per $\mathrm{g}$ of soil, estimated according to van Groenigen et al. (2010). This ratio turned out to be equal (0.53) for both soils with different tillage history, probably due to the relative short time lap since the conversion of tillage management compared to the relative long residence time of amino sugars in soils after cell death (Glaser and Gross 2005) and to the larger uncertainty on the muramic acid concentrations.

Crop residue input is not different between conventional and no-till treatment (Table 1), but tillage redistribute the residue input over the plow depth. Therefore, the annual $\mathrm{C}$ input in the $0-10 \mathrm{~cm}$ topsoil is around $0.7 \mathrm{mg} \mathrm{C} \mathrm{g}^{-1}$ dry soil higher for the not tilled site, assuming an evenly distributed of the crop residue over the entire plowing depth in the tilled site. The annual net difference of amino sugar content between the tilled and the no-till site was calculated as $6.7 \pm 1.8 \%$ for glucosamine, $2.8 \pm 2.2 \%$ for galactosamine and $6.5 \pm 14 \%$ for muramic acid. Meanwhile, the average proportion of $\mathrm{AS}_{\mathrm{R}, \mathrm{Max}}$ to the original amino sugar content for leaf and root (grain was left out since it is not incorporated in situ) was respectively $3.9 \%$ for glucosamine, $2.6 \%$ for galactosamine upon crop residues in this study.

Both from field measurement and laboratory incubations we observed that the relative change of galactosamine was significantly smaller than for glucosamine (Table 4), indicating that the more conservative response of galactosamine upon shift in tillage was (at least partially) due to a lower formation of residue derived galactosamine 
403 compared to glucosamine after receiving increased residue input in the no-till 404 treatment.

\section{5. Conclusions:}

407 A first-order kinetic model could describe residue derived amino sugar formation, 408 which reached a maximum and steady state several days after residue addition.

409 During peak microbial activity de novo residue derived amino sugar formation was 410 surprisingly fast, giving shorter mean production times (MPT) for glucosamine (2.1 4115.0 days) than for galactosamine (2.5 - 9.3 days). The faster incorporation of residue 412 carbon into glucosamine compared to the dominantly fungal galactosamine, 413 underpinned the role of bacteria as 'fast energy channel' described by Rousk and 414 Bååth (2007). In addition the de novo amino sugar formation relative to original 415 amino sugar pool was higher for glucosamine than for galactosamine, however this 416 difference declined strongly with decreasing residue quality, confirming the better 417 adaptation of fungal communities to colonize more recalcitrant $\mathrm{C}$ sources. Finally, the 418 influence of tillage history on de novo amino sugar formation indicated a better 419 adaptation of soil microbial community in the no-till treatment compared to 420 conventional tillage to incorporate carbon originating from more recalcitrant plant 421 residues.

\section{Acknowledgements}

424 We thank Katja Van Nieuland and Jan Vermeulen for ${ }^{13} \mathrm{C}$ analysis of bulk soil and $425 \mathrm{CO}_{2}$. We would like to acknowledge Karolien Denef and Joan Six for providing the 426 labeled plant material. Dries H. is a postdoctoral fellow of the Fund for Scientific 427 Research - Flanders (FWO). Zhen Bai's scientific mission was financed by the 428 National Natural Science Foundation of China and the "Departement Onderwijs en 429 Vorming" of the Flemish Government. Finally the authors would like to express their 430 gratitude to Prof. Dr. J. Schimel and two anonymous reviewers for their very valuable 431 remarks and comments. 


\section{References}

Acosta-Martinez, V., Zobeck, T.M., Gill, T.E., Kennedy, A.C., 2003. Enzyme activities and microbial community structure in semiarid agricultural soils. Biology and Fertility of Soils 38, 216-227.

Allison, S.D., Wallenstein, M.D., Bradford, M.A., 2010. Soil-carbon response to warming dependent on microbial physiology. Nature Geoscience 3, 336-340.

Amelung, W., Brodowski, S., Sandhage-Hofmann, A., Bol, R., 2008. Combining Biomarker with Stable Isotope Analyses for Assessing the Transformation and Turnover of Soil Organic Matter. Advances in Agronomy, Vol 100 100, 155-250.

Amelung, W., Miltner, A., Zhang, X., Zech, W., 2001. Fate of microbial residues during litter decomposition as affected by minerals. Soil Science 166, 598-606.

Appuhn, A., Joergensen, R.G., Raubuch, M., Scheller, E., Wilke, B., 2004. The automated determination of glucosamine, galactosamine, muramic acid, and mannosamine in soil and root hydrolysates by HPLC. Journal of Plant Nutrition and Soil Science-Zeitschrift Fur Pflanzenernahrung Und Bodenkunde 167, 17-21.

Blagodatskaya, E.V., Blagodatsky, S.A., Anderson, T.H., Kuzyakov, Y., 2007. Priming effects in Chernozem induced by glucose and $\mathrm{N}$ in relation to microbial growth strategies. Applied Soil Ecology 37, 95-105.

Bell, J.M., Smith, J.L., Bailey, V.L., Bolton, H., 2003. Priming effect and C storage in semi-arid no-till spring crop rotations. Biology and Fertility of Soils 37, 237-244.

Bodé, S., Denef, K., Boeckx, P., 2009. Development and evaluation of a high-performance liquid chromatography/isotope ratio mass spectrometry methodology for delta(13)C analyses of amino sugars in soil. Rapid Communications in Mass Spectrometry 23, 2519-2526.

Boeckx, P., Van Nieuland, K., Van Cleemput, O., 2011. Short-term effect of tillage intensity on N2O and CO2 emissions. Agronomy for Sustainable Development 31, $453-461$

Decock, C., Denef, K., Bode, S., Six, J., Boeckx, P., 2009. Critical assessment of the applicability of gas chromatography-combustion-isotope ratio mass spectrometry 
to determine amino sugar dynamics in soil. Rapid Communications in Mass Spectrometry 23, 1201-1211.

Denef, K., Six, J., 2006. Contributions of incorporated residue and living roots to aggregate-associated andmicrobial carbon in two soilswith different claymineralogy. European Journal of Soil Science 57, 774-786 .

Derrien, D., Amelung, W., 2011. Computing the mean residence time of soil carbon fractions using stable isotopes: impacts of the model framework. European Journal of Soil Science 62, 237-252.

471 Derrien, D., Marol, C., Balabane, M., Balesdent, J., 2006. The turnover of 472 carbohydrate carbon in a cultivated soil estimated by (13)C natural abundances. 473 European Journal of Soil Science 57, 547-557.

474 Ding, X.L., Zhang, X.D., He, H.B., Xie, H.T., 2010. Dynamics of soil amino sugar 475 pools during decomposition processes of corn residues as affected by inorganic $\mathrm{N}$ 476 addition. Journal of Soils and Sediments 10, 758-766.

477 Engelking, B., Flessa, H., Joergensen, R.G., 2007. Shifts in amino sugar and 478 ergosterol contents after addition of sucrose and cellulose to soil. Soil Biology \& $479 \quad$ Biochemistry 39, 2111-2118.

480 FAO, 2006. World reference base for soil resources. Report 013. FAO, Rome, p 86

481 Farkas, V., 1979. Biosynthesis of Cell-Walls of Fungi. Microbiological Reviews 43, $482 \quad 117-144$.

483 Fu, S.L., Coleman, D.C., Schartz, R., Potter, R., Hendrix, P.F., Crossley, D.A., 2000. 484 C-14 distribution in soil organisms and respiration after the decomposition of crop 485 residue in conventional tillage and no-till agroecosystems at Georgia Piedimont. $486 \quad$ Soil \& Tillage Research 57, 31-41.

487 Glaser, B., Gross, S., 2005. Compound-specific delta C-13 analysis of individual 488 amino sugars - a tool to quantify timing and amount of soil microbial residue 489 stabilization. Rapid Communications in Mass Spectrometry 19, 1409-1416.

490 Glaser, B., Turrion, M.B., Alef, K., 2004. Amino sugars and muramic acid 491 biomarkers for soil microbial community structure analysis. Soil Biology \& $492 \quad$ Biochemistry 36, 399-407. 
He, H.B., Li, X.B., Zhang, W., Zhang, X.D., 2011a. Differentiating the dynamics of native and newly immobilized amino sugars in soil frequently amended with inorganic nitrogen and glucose. European Journal of Soil Science 62, 144-151.

He, H.B., Xie, H.T., Zhang, X.D., Wang, Y.H., Wu, Y.Y., 2005. A gas chromatographic/mass spectrometric method for tracing the microbial conversion of glucose into amino sugars in soil. Rapid Communications in Mass Spectrometry 19, 1993-1998.

He, H.B., Zhang, W., Zhang, X.D., Xie, H.T., Zhuang, J., 2011b. Temporal responses of soil microorganisms to substrate addition as indicated by amino sugar differentiation. Soil Biology \& Biochemistry 43, 1155-1161.

Liang, C., Balser, T.C., 2010. Mass spectrometric characterization of amino sugar aldononitrile acetate derivatives used for isotope enrichment assessment of microbial residues. Soil Biology \& Biochemistry 42, 904-909.

Liang, C., Zhang, X.D., Rubert, K.F., Balser, T.C., 2007. Effect of plant materials on microbial transformation of amino sugars in three soil microcosms. Biology and Fertility of Soils 43, 631-639.

Marx, M., Buegger, F., Gattinger, A., Zsolnay, A., Munch, J.C., 2010. Determination of the fate of regularly applied (13)C-labeled-artificial-exudates $\mathrm{C}$ in two agricultural soils. Journal of Plant Nutrition and Soil Science 173, 80-87.

Mauck, J., Chan, L., Glaser, L., 1971. Turnover of the cell wall of Gram-positive bacteria. J Biol Chem 246, 1820-1827.

Myers, R.T., Zak, D.R., White, D.C., Peacock, A., 2001. Landscape-level patterns of microbial community composition and substrate use in upland forest ecosystems. Soil Science Society of America Journal 65, 359-367.

Park, J.T., 2001. Identification of a dedicated recycling pathway for anhydro-N-acetylmuramic acid and $\mathrm{N}$-acetylglucosamine derived from Escherichia coli cell wall murein. Journal of Bacteriology 183, 3842-3847.

Perelo, L.W., Munch, J.C., 2005. Microbial immobilisation and turnover of (13)C labelled substrates in two arable soils under field and laboratory conditions. Soil Biology \& Biochemistry 37, 2263-2272. 
Rousk, J., Bååth, E., 2007. Fungal and bacterial growth in soil with plant materials of different C/N ratios. Fems Microbiology Ecology 62, 258-267.

Reinhold-Hurek, B., Hurek, T., 2011. Living inside plants: bacterial endophytes. Current Opinion in Plant Biology 14, 435-443.

Sauheitl, L., Glaser, B., Bol, R., 2005. Short-term dynamics of slurry-derived plant and microbial sugars in a temperate grassland soil as assessed by compound-specific delta C-13 analyses. Rapid Communications in Mass Spectrometry 19, 1437-1446.

Thiet, R.K., Frey, S.D., Six, J., 2006. Do growth yield efficiencies differ between soil microbial communities differing in fungal: bacterial ratios? Reality check and methodological issues. Soil Biology \& Biochemistry 38, 837-844.

van Groenigen, K.J., Bloem, J., Bååth, E., Boeckx, P., Rousk, J., Bode, S., Forristal, D., Jones, M.B., 2010. Abundance, production and stabilization of microbial biomass under conventional and reduced tillage. Soil Biology \& Biochemistry 42, 48-55.

Waldrop, M.P., Firestone, M.K., 2004. Microbial community utilization of recalcitrant and simple carbon compounds: impact of oak-woodland plant communities. Oecologia 138, 275-284.

Werth, M., Kuzyakov, Y., 2010. (13)C fractionation at the root-microorganisms-soil interface: A review and outlook for partitioning studies. Soil Biology \& Biochemistry 42, 1372-1384.

White, P.A., Rice, C.W., 2009. Tillage Effects on Microbial and Carbon Dynamics during Plant Residue Decomposition. Soil Science Society of America Journal 73, 138-145.

White, R.J., 1968. Control of Amino Sugar Metabolism in Escherichia Coli and Isolation of Mutants Unable to Degrade Amino Sugars. Biochemical Journal 106, 847-858. 


\section{Appendix 1: mean production time}

552 Similarly to the mean residence time (MRT) of a litter cohort in the soil reservoir 553 introduced by Derrien and Amelung (2011) the mean production time (MPT) defined 554 here as the average time needed to form "de novo" amino sugars following plant 555 residue addition can be estimated by equation (6), this can be found by rewriting 556 equation (5) as :

$557 \quad\left(\mathrm{AS}_{\mathrm{R}, \operatorname{Max}}-\mathrm{AS}_{\mathrm{R}}\right)_{(\mathrm{t})}=\mathrm{AS}_{\mathrm{R}, \operatorname{Max}} \cdot \mathrm{e}^{-k \cdot \mathrm{t}}$

558 The difference $\left(\mathrm{AS}_{\mathrm{R}, \mathrm{Max}}-\mathrm{AS}_{\mathrm{R}}\right)$ follows an exponential decrease and the change of $559\left(\mathrm{AS}_{\mathrm{R}, \mathrm{Max}}-\mathrm{AS}_{\mathrm{R}}\right)$ in function of time can be written as:

$560 \frac{\mathrm{d}\left(\mathrm{AS}_{\mathrm{R}, \operatorname{Max}}-\mathrm{AS}_{\mathrm{R}}\right)}{\mathrm{dt}}=-k \cdot\left(\mathrm{AS}_{\mathrm{R}, \text { Max }}-\mathrm{AS}_{\mathrm{R}}\right)$

561 Since the change in this difference $\left[\mathrm{d}\left(\mathrm{AS}_{\mathrm{R}, \mathrm{Max}}-\mathrm{AS} \mathrm{S}_{\mathrm{R}}\right)\right]$ is equal to the negation of the 562 change in amount residue derived amino sugar $\left[-\mathrm{d}\left(\mathrm{A} \mathrm{S}_{\mathrm{R}}\right)\right]$. The amount residue derived 563 amino sugar formed during a time interval from $\mathrm{t}$ to $\mathrm{t}+\mathrm{dt}$ is thus equal to:

$$
\mathrm{d}\left(\mathrm{AS}_{\mathrm{R}}\right)=k \cdot\left(\mathrm{AS}_{\mathrm{R}, \mathrm{Max}}-\mathrm{AS}_{\mathrm{R}}\right) \mathrm{dt}
$$

565 The time needed to form a portion $\mathrm{d}\left(\mathrm{AS}_{\mathrm{R}}\right)_{(\mathrm{t})}$ out of the added residue, is equal to $\mathrm{t}$ and 566 this portion is a fraction $\mathrm{d}\left(\mathrm{AS}_{\mathrm{R}}\right)_{(\mathrm{t})} / \mathrm{AS}_{\mathrm{R}, \text { Max }}$ of the total amount $A S_{\mathrm{R}, \text { Max }}$ that will be 567 formed during the exponential de novo amino sugar formation. So that the mean 568 production time (MPT) can be calculated by integration from start of the incubation 569 till end of the exponential de novo amino sugar formation $\left(\mathrm{t}_{\mathrm{Max}}\right)$ :

$$
\begin{aligned}
& \mathrm{MPT}=\frac{1}{\mathrm{AS}_{\mathrm{R}, \text { Max }}} \int_{0}^{\mathrm{t}_{\mathrm{Max}}} \mathrm{t} \times \mathrm{d}\left(\mathrm{AS}_{\mathrm{R}}\right)_{(\mathrm{t})} \\
& \mathrm{MPT}=\frac{1}{\mathrm{AS} S_{\mathrm{R}, \text { Max }}} \int_{0}^{\mathrm{t}_{\mathrm{Max}}} \mathrm{t} \times k\left(\mathrm{AS}_{\mathrm{R}, \text { Max }}-\mathrm{AS}_{\mathrm{R}}\right) \mathrm{dt} \\
& \mathrm{MPT}=\frac{1}{\mathrm{AS}_{\mathrm{R}, \text { Max }}} \int_{0}^{t_{\operatorname{Max}}} \mathrm{t} \cdot k \cdot \mathrm{AS}_{\mathrm{R}, \text { Max }} \cdot \mathrm{e}^{-k \mathrm{t}} \mathrm{dt}=k \int_{0}^{\mathrm{t}_{\operatorname{Max}}} \mathrm{t} \cdot \mathrm{e}^{-\mathrm{kt}} \mathrm{dt}
\end{aligned}
$$

570 And by integration by parts.

$571 \quad \mathrm{MPT}=\frac{1}{\mathrm{k}}$ 